\title{
CANNULATED SCREW AND HEXAPODAL FIXATOR RECONSTRUCTION FOR COMPOUND UPPER TIBIAL FRACTURES
}

\author{
Metin UzUN ${ }^{1}$, FiKRI ERKAL BILEN ${ }^{2}$, LeVENT ERALP ${ }^{3}$
}

\begin{abstract}
Objectives: The aim of the treatment of tibial plateau fractures is to obtain a pain-free and fully functional knee with closed reduction, percutaneous cannulated screw fixation and hexapodal external fixator reconstruction for high energy compound upper tibial fractures. Methods: Patients with comminuted tibial plateau fractures underwent closed reduction, percutaneous fixation with cannulated screws, and reconstruction with hexapodal external fixator. The follow-up period was 24 months.
\end{abstract}

Results: The clinical and radiological results were good or excellent. The average knee flexion was $125^{\circ}$. Conclusion: Our results are successful in the initial stage, however, it should be pointed out that during the long term follow-up osteoarthritis may develop leading to worsening of the condition. Level of Evidence IV, Case Series.

Keywords: Knee injuries/sugery. External fixators. Tibial fractures. Intra-articular fractures.

Citation: Uzun M, Bilen FE, Eralp L. Cannulated screw and hexapodal fixator reconstruction for compound upper tibial fractures. Acta Ortop Bras. [online]. 2014;22(1):43-7. Available from URL: http://www.scielo.br/aob.

\section{INTRODUCTION}

The knee is one of the most important weight-bearing joints and it is often subjected to trauma due to its location in the body. ${ }^{1,2}$ Tibial plateau fractures occur often among knee fractures. The aim in the treatment of tibial plateau fractures is to obtain a stable, pain-free and fully functioning knee., ${ }^{1,2}$ Despite the various treatment options available, either by external or internal methods, the treatment of comminuted tibial plateau fractures often yield to unsatisfactory results, related to prolonged immobilization and development of osteoarthritic changes.

In this study we present our clinical and radiological results and our surgical technique as a closed reduction, percutaneous cannulated screw fixation and hexapodal external fixator the treatment of tibial plateau fractures in three patients.

\section{PATIENTS AND METHODS}

Between 2009 and 2010, the treatment of three male patients (mean age 47 years old; range 39 to 61 years) with comminuted tibial plateau fractures was performed under fluoroscopy control. Closed reduction was performed by using a Kirschner wire as a joystick and a periostal elevator. Then, the major fragments were fixed using a headless cannulated screw to obtain rigid fixation of the proximal tibial articular surface. The continuity of the stabilization between the articular surface and the tibial diaphysis was then obtained by application of a hexapodal external fixator (Smart Gotham, New Jersey, USA). (Figure 1) None of the patients had any vascular or neural lesions at the time of admittance. One of the patients exhibited ipsilateral quadriceps atrophy related to a previous anterior cruciate ligament injury. The remaining two patients did not have any lower extremity alignment problems, nor intraarticular pathologies including meniscal tear, chondral lesion, or ligament injury. There was no surgical history of the knee, hip or ankle in any patient. All three patients sustained motor vehicle accidents, two were inside the vehicle, and one was hit by a vehicle. The classification of the patients fractures was done according to Schatzker classification. ${ }^{3}$ Two of the patients were type 5 , and the other was type 6. (Figures 2 and 3 ) The clinical results of our cases were evaluated according to the Knee Society Criteria. ${ }^{4}$ Resnic and Niwoyama ${ }^{5}$ criteria were used for radiological evaluation.

\section{Surgical Technique:}

The lower extremity was prepared sterile under epidural anesthesia combined with sedation. The fracture hematoma was

All the authors declare that there is no potential conflict of interest referring to this article.

\footnotetext{
1. Acıbadem Maslak Hospital. Trauma Surgery, Sarıyer, Istanbul, Turkey.

2. Memorial Hospital.Trauma Surgery, Okmeydanı, Istanbul,Turkey.

3. İstanbul Medicine Faculty. Trauma Surgery, Istanbul,Turkey

Study conducted at Acıbadem Maslak Hospital, Istanbul, Turkey.

Mailing address: Darüşşafaka str. Büyükdere str No:40 Maslak/Sarıyer/istanbul/Turkey. drmetinuzun@gmail.com
} 


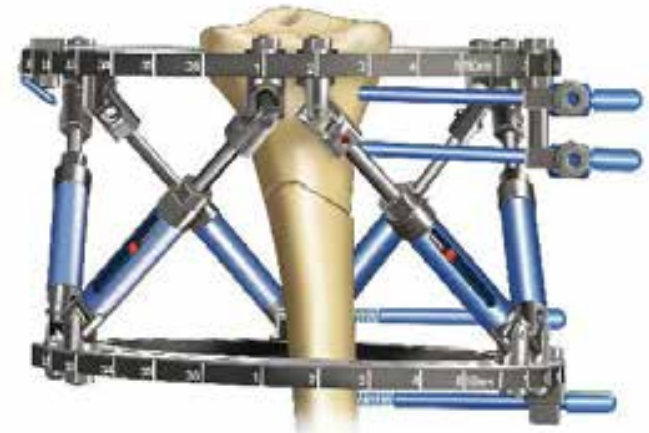

Figure 1. Hexapodal external fixator.

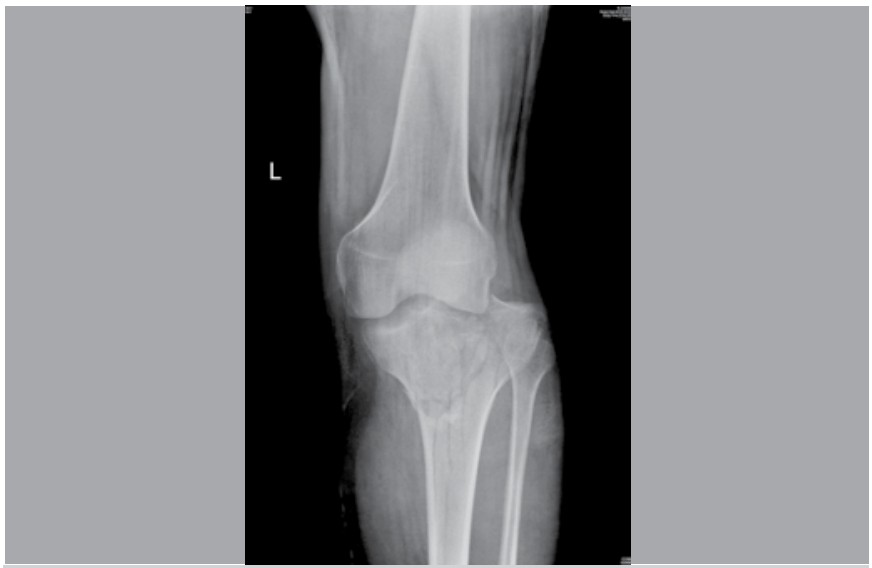

Figure 2. AP view of the knee of a 39 years old man showing compound intraarticular tibia fracture.

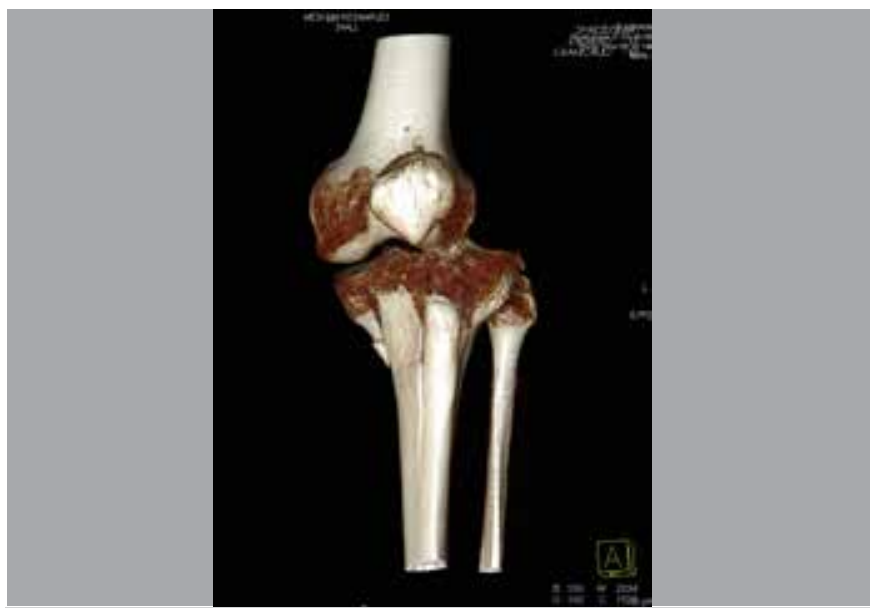

Figure 3. Frontal CT image of the knee showing compound intraarticular tibia fracture.

aspirated and the joint was irrigated with arthroscopic trochar. Under fluoroscopic control, the fragments were reduced with help of a Kirschner ( $\mathrm{K}$ ) wire acting as a joystick and a periostal elevator. Once the joint line was anatomically repositioned, confirmed by fluoroscopic control, the fragments were fixed with two or three headless cannulated screws (Acumed, Oregon, USA), as needed. (Figures 4 and 5) After the joint line was stabilized, the external fixator system consisting of two rings was applied to complete the osteosynthesis. Two cross Schanz pins and one $\mathrm{K}$ wire were used to fix the proximal ring to the proximal tibia. (Figures 6 and 7) The two rings were connected using the six axis system. Four Schanz pins were used to fix the distal ring to the tibial shaft. (Figure 8) A dynamic knee imaging with the fluoroscope was done on both the anteroposterior and lateral views. After it was stabilized, the surgical procedure was completed. All patients received epidural anaesthesia to enable early mobilization on the day of surgery. Continuous Passive Motion (CPM) was utilized as tolerated, and quadriceps isometric exercises were initiated. All patients walked the same day with two crutches without weight-bearing. Any residual deformity at the proximal tibia was corrected using a computer-assisted five-day correction program. The residual deformity was calculated on the postoperative anteroposterior and lateral X-rays.

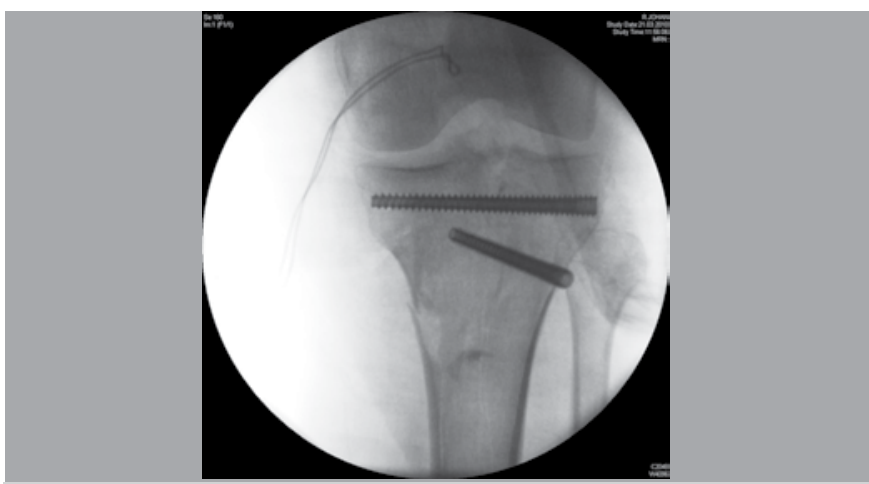

Figure 4. AP view of the knee which joint line was anatomically fixed with headless cannulated screws.

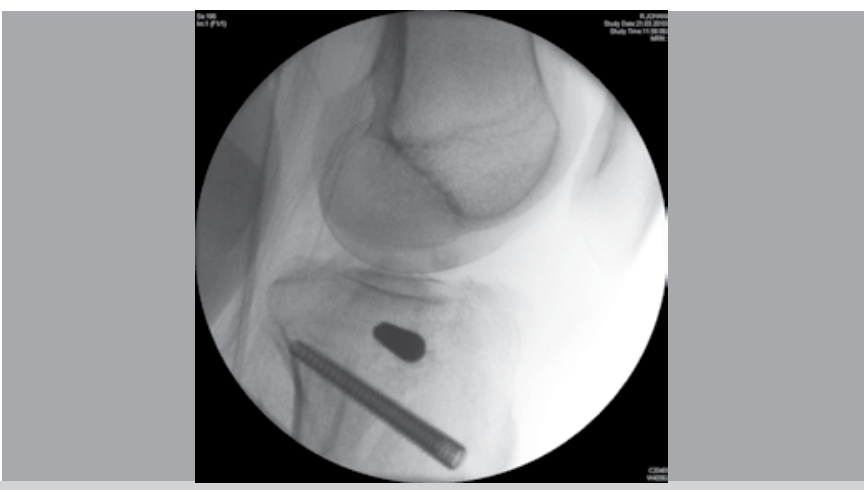

Figure 5. Lateral view of the knee which joint line was anatomically fixed with headless cannulated screws.

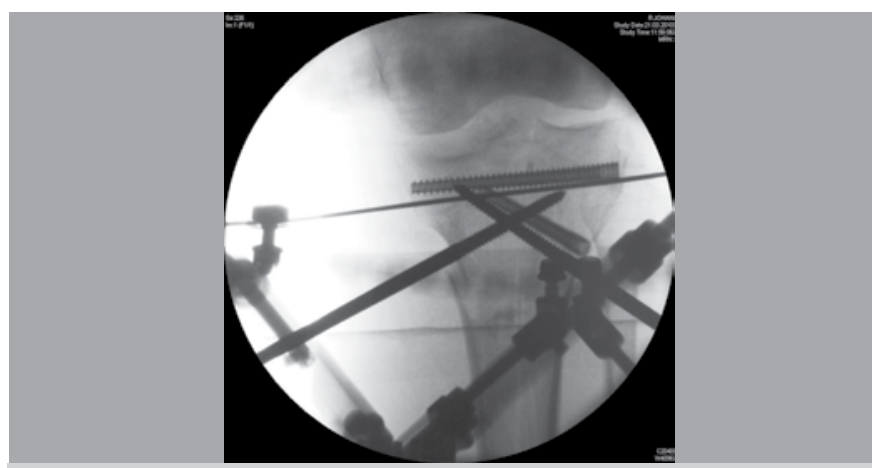

Figure 6. AP view of the knee which proximal part of fracture was fixed with cross Schanz pins and one $\mathrm{K}$ wire. 
(Figures 9 and 10) Control X-rays were obtained on the fifth day postoperative. (Figures 11 and 12) The next control was performed at the 8-week follow-up visit, during which the posterior half of the proximal ring was removed to allow. The external fixator was removed at $10^{\text {th }}$ to $12^{\text {th }}$ postoperative week under sedation in the operative room. Then, all patients were allowed to put weight on the knee as tolerated. (Figures 13 and 14)

\section{RESULTS}

The follow-up period was 12 months. Bone healing occured on average at the $11^{\text {th }}$ week (range, 10 to 12 weeks). No delayed union or nonunions were found. The average external fixation time was 75 days (range, 70 to 85 days). The clinical results were excellent in all patients according to Knee

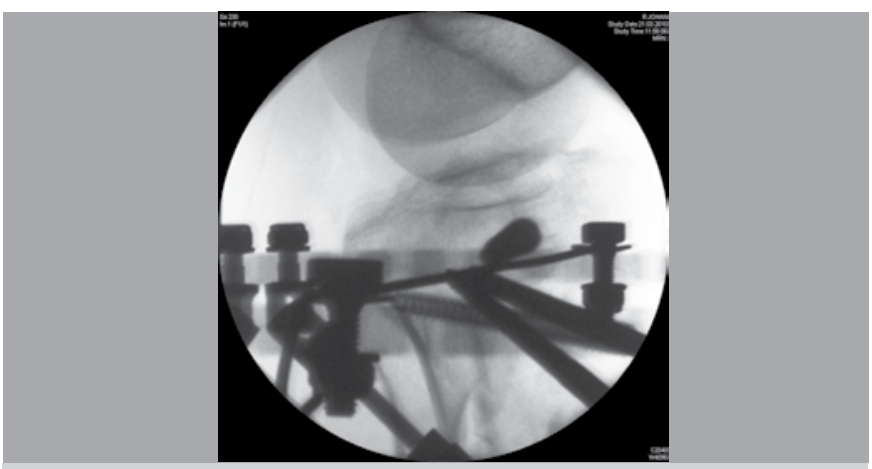

Figure 7. Lateral view of the knee which proximal part of fracture was fixed with cross Schanz pins and one K wire.

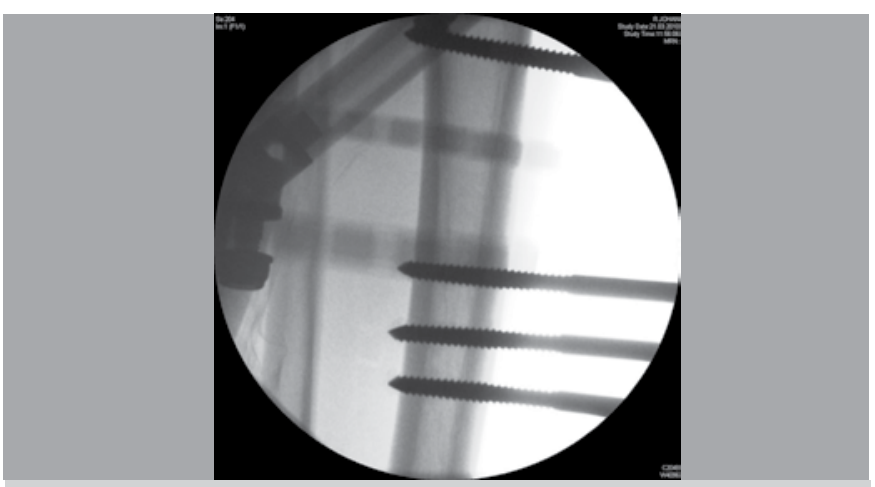

Figure 8. AP view of the tibia with Schanz pins which were used to fix the distal ring to the tibia.

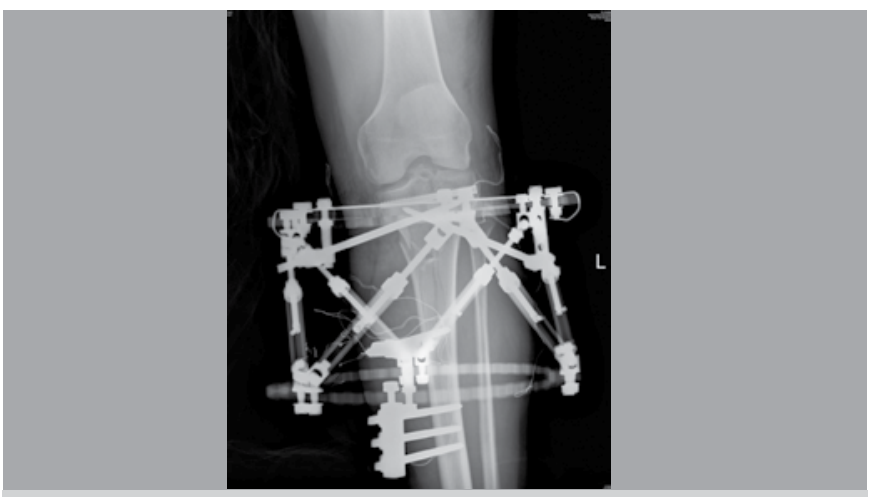

Figure 9. AP of the knee at the $1^{\text {st }}$ postoperative day.

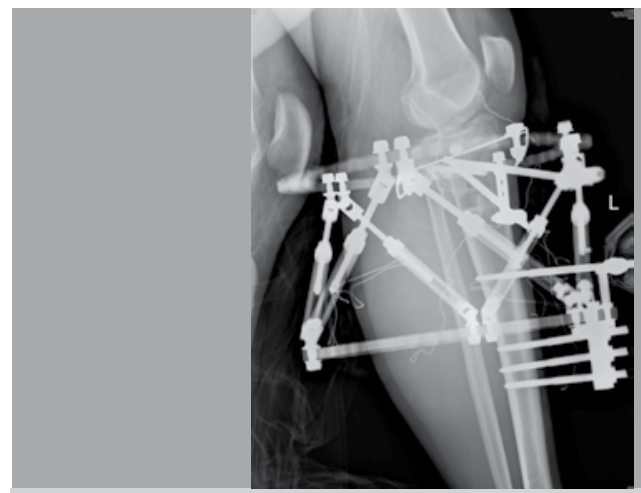

Figure 10. Lateral view of the knee at the $1^{\text {st }}$ postoperative day.

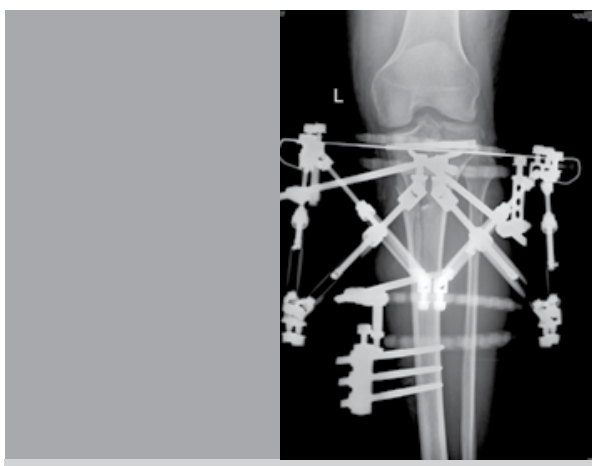

Figure 11. AP view of the knee after the deformity was corrected at the $5^{\text {th }}$ postoperative day.

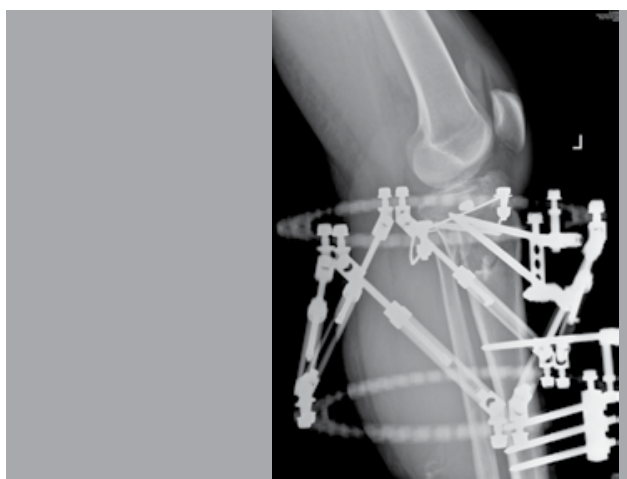

Figure 12. Lateral view of the knee after the deformity was corrected at the $5^{\text {th }}$ postoperative day.

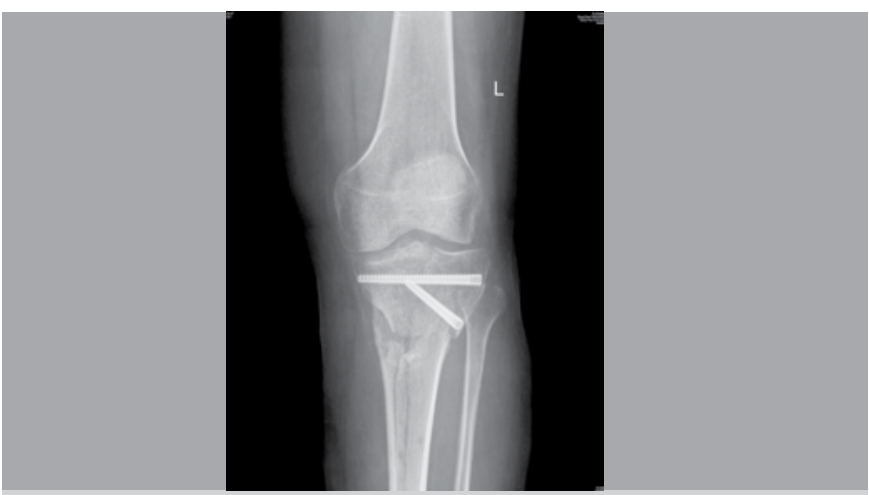

Figure 13. AP view of the knee after the fixator was removed. 
Society Criteria. ${ }^{4}$ (Figures 15 and 16) The average knee flexion was $125^{\circ}$ (range, $123^{\circ}$ to $127^{\circ}$ ). In radiological evaluations, all three cases exhibited good results according to Resnic and Niwoyama ${ }^{5}$. (Figures 17 and 18)

There was no residual proximal tibial deformity in any of three cases and we did not find any knee flexion contractures. One patient displayed anterior knee instability because of deficiency Anterior Cruciate Ligament (ACL) history, which was treated conservatively, and deep venous thrombosis developed in another patient, which was resolved by anticoagulant treatment. Pin track infection was observed in one patient which was treated satisfactorily by local wound care and oral antibiotics. The average hospital stay duration was 5 days.

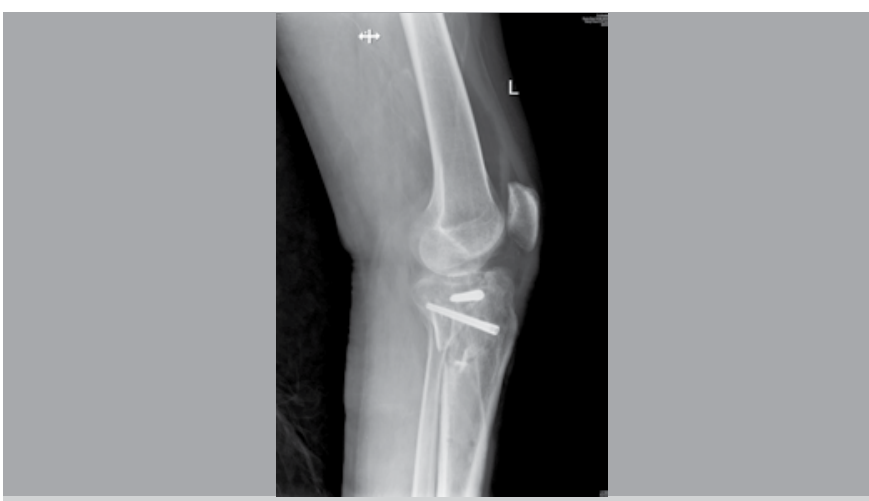

Figure 14. Lateral view of the knee after the fixator was removed.

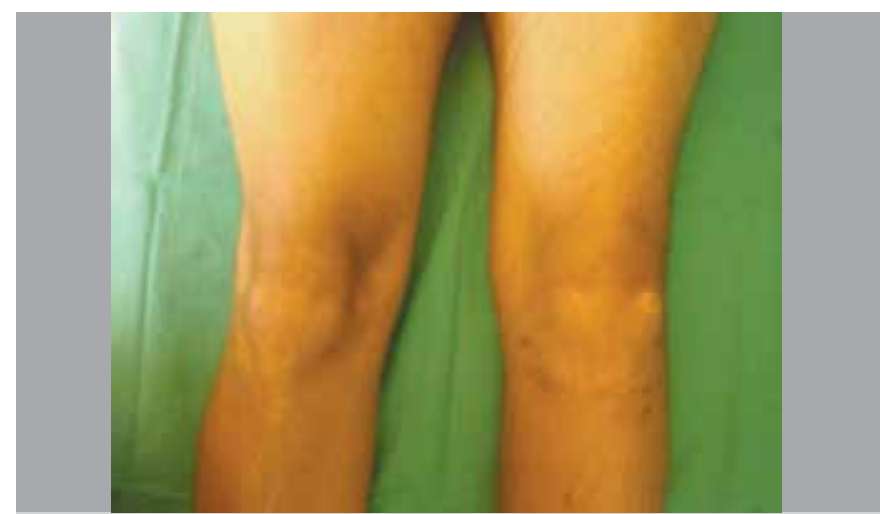

Figure 15. AP clinical image of the knee at the $12^{\text {th }}$ postoperative month.

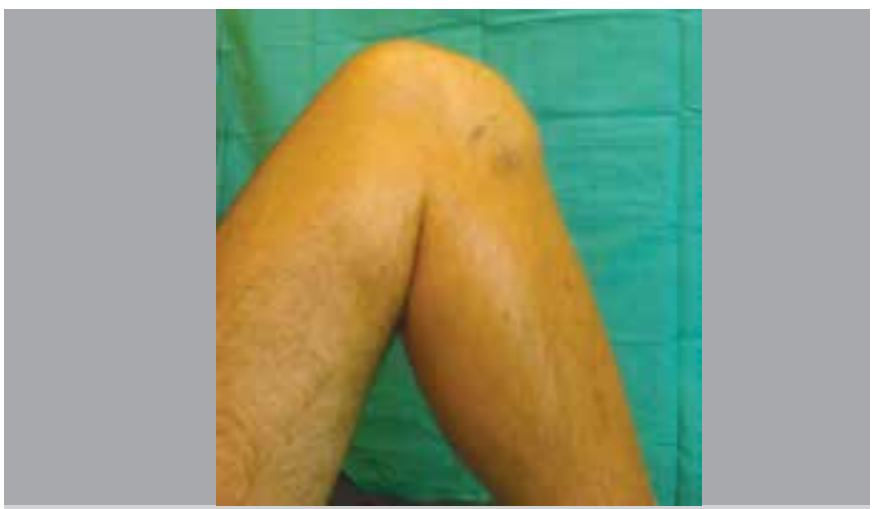

Figure 16. Lateral clinical image of the knee at the $12^{\text {th }}$ postoperative month.

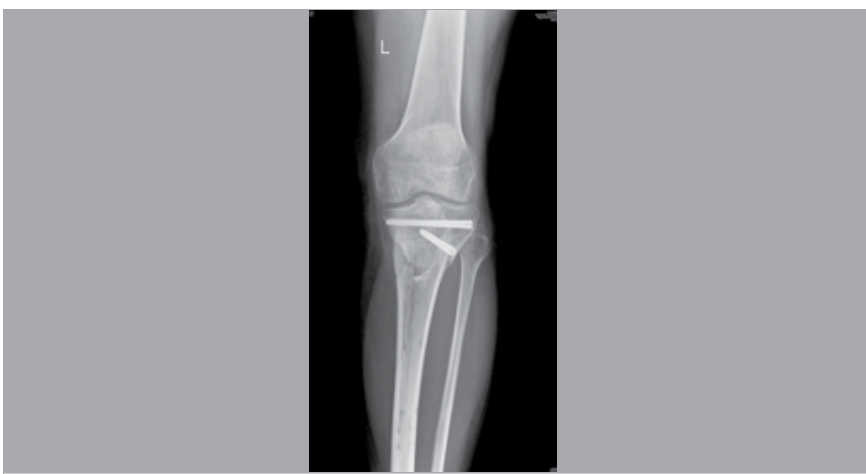

Figure 17. AP view of the knee at the $12^{\text {th }}$ postoperative month.

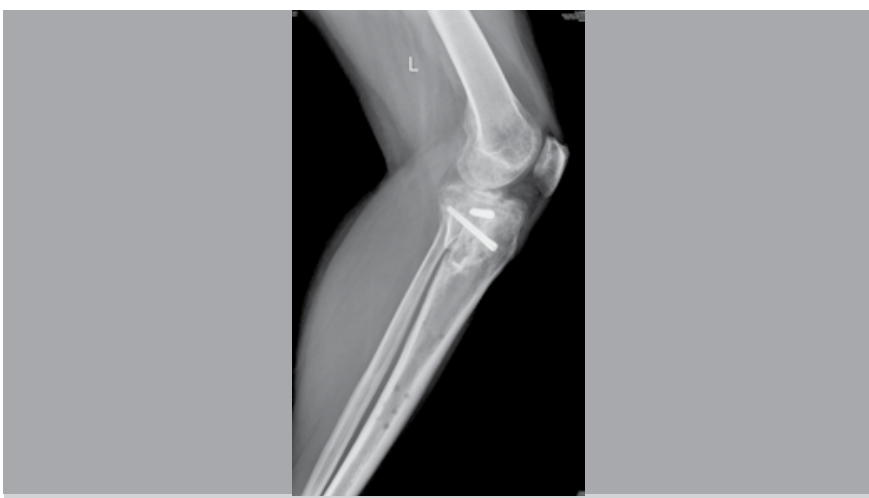

Figure 18. Lateral view of the knee at the $12^{\text {th }}$ postoperative month.

\section{DISCUSSION}

The aim of the treatment of tibial plateau fractures is to achieve pain-free, stable knee with full range-of-motion. ${ }^{6-9}$ Various treatment methods were described in the literature and applied over time including closed reduction and cast application, skeletal traction, external fixators, open reduction and internal fixation, and arthroscopy assisted procedures..$^{2,7,9-13}$

The displacement of the fracture fragments, step off on the articular surface, and instability are the main criteria for surgical indication. $3,9,14$ The high failure rate of correction loss and varus deformity development, as a result of constructive treatment in especially medial joint surface, supports these criteria. ${ }^{15}$ Both the displacement of bone fragments and any step off on the articular surface must be anatomically corrected. Even if the displacement is corrected, but there is a residual step off at the joint surface, this might result in post-traumatic arthritis in the future. $3,5,9,10$

Tibial plateau fractures occuring as a result of high-energy traumas are usually Schatzker types 5 or $6 .{ }^{9}$ Infection, soft tissue problems and deep venous thrombosis are observed relatively often during the treatment of these types of fractures. ${ }^{7,9,11}$ Preferably, meticulous soft tissue disection with least possible additional trauma must be carried out during surgical treatment. ${ }^{9}$ In his study, Jiang et al. ${ }^{16}$ compared double plating using Less Invasive Stabilization System (LISS) method and has reported that in proximal tibia fractures, malaligment and hardware irritations occur more frequently. Krupp et al. ${ }^{17}$ in their comparative study of external fixation and locking plate applications in the treatment of bicondyler tibial plateau fractures, reported that 
joint stiffness, complication rate and malunions are less observed when external fixation methods were used. Soft tissue problems (compartment syndrome, tissue closing problems, etc.) and the high rate of infection in internal stabilization methods, and the high probability of development of compartment syndrome in arthroscopy-assisted methods favor the more preferrable external fixation methods. ${ }^{12,18}$ Since tourniquets are not used in surgical procedure, our method has less risk of neurapraxia, deep venous thrombosis and circulatory problems. Schatzker et al. ${ }^{3}$ has suggested surgical treatment in all fractures causing joint instability, and has stated the importance of anatomic reduction and rigid internal fixation for healing of the cartilage at the fracture site. In this current technique, osteosynthesis was attained first by the reduction of the bone fragments forming the joint line as possible as an anatomic shape of the tibia and fixing them by cannulated screws so that the proximal part is converted into a piece with a level joint line.

Rasmussen ${ }^{14}$ has observed that in lower extremity tibia fractures osteoarhtritis and instability and angular deformity have a close relationship, and in angular deformities exceeding $10^{\circ}$ osteoarthritis is higher. External fixation methods are used to correct angular deformities. Classic circular llizarov rings or six axis systems can be used, alternatively. ${ }^{19}$

Rozbruch et al. ${ }^{19}$ has reported successful results with the six axis system in the treatment of tibial deformities. Manner et al. ${ }^{20}$ has reported $90.7 \%$ versus $55.7 \%$ success rates with six axis system compared to llizarov ring fixators to best correct deformities. Because of the web based six axis system, better results and lower complication rates are obtained while correcting multiplanar deformities. Hexapod system is a preferred method enabling the correction of the deformities that could occur post-surgery or during the treatment of tibial plateau fractures. Therefore, we believe that using the six axis system compared with the classical external fixation methods will reduce the risk of malunion.

Rigid stabilization and early joint mobilization are of paramount importance in the treatment of intra-articular fractures. 3,14 Joint motion is very important for cartilage nutrition, as it reduces the risk for development of osteoarthritis. ${ }^{3,14}$ The largest barrier for initiating early motion is pain. Patients usually prefer keeping the area immobile to decrease pain. We applied epidural anaesthesia for pain control which was continued for five days, since the planning for correcting angulation was that long. Early range-of-motion painless exercises were, thus, started at the day of surgical procedure.

\section{CONCLUSION}

Using this method, our early stage results were successful and there were no complications; however, it should be noted that, on long term follow up osteoarthritis may appear and cause deterioration of clinical results.

\section{REFERENCES}

1. Apley AG. Fractures of the lateral tibial condyle treated by skeletal traction and early immobilization. J Bone Joint Surg Br. 1956;38(3):699-712.

2. Aşık M, Çetik O, Talu U, Sozen YV. Arthroscopy-assisted operative management of tibial plateau fractures. Knee Surg Sports Traumatol Arthrosc. 2002; 10(6):364-70

3. Schatzker J, McBroom R, Bruce D. The tibial plateau fracture: The Toronto experience 1968 -1975. Clin Orthop Relat Res. 1979;(138):94-107.

4. Insall JN, Dorr LD, Scott RD, Scott WN. Rationale of the Knee Society clinical rating system. Clin Orthop Relat Res. 1989;(248):13-4.

5. Resnick O, Niwayama G. Diagnosis of bone and joint disorders. Philadelphia: Saunders; 1998.

6. Bowes DN, Hohl M.Tibial condylar fractures. Evaluation of treatment and outcome. Clin Orthop Relat Res. 1982;(171):104-8.

7. Bulent A, Ozturk K. Olcay E. Basic B. Surgical treatment for tibial plateau fractures. Acta Orthop Traumatol Turc. 1995;29(2):133-5.

8. Gousewitz S, Hohl M. The significance of early motion in the treatment of tibial plateau fractures. Clin Orthop Relat Res. 1986;(202):135-8.

9. Işıklar ZU. Diz çevresi kırıklar. In: Tandoğan RN, Alpaslan AM, editors. Diz cerrahisi. Ankara: Haberal Eğitim Vakfı; 1998. p. 399-418.

10. Uzun M, Akman S, Seçkin F, Ertürer E, Bülbül M. Konservatif Tedavi UyguIanan Plato Tibia Kırıklarında Radyolojik ve Fonksiyonel Sonuçlar Uyumlu mudur? Nobel Med. 2011;7(3):53-9.

11. Muratı HH, Yüksel HY, Çelebi L, Biçimoğlu A, Tabak Y. Tibia Plato Kırıklarında Yükseltme, Greftleme ve Internal Tespitle Tedavi Sonuçlarımız. J Arthropl Arthrosc Surg. 2003;14(4):222-9.
12. Oguz E, Yanmıs I, Kurklu M, Atesalp AS, Yildiz C. Bikondiler tibia kırıklarında artroskopi destekli eksternal fiksatör osteosentezi sonuçları. Acta Orthop Traumatol Turc. 2007;41(1):1-6.

13. Scotland T, Wardlaw $D$. The use of cast-bracing as treatment for fractures of the tibial plateau. J Bone Joint Surg Br. 1981;63(4):575-8.

14. Rasmussen PS. Tibial condylar fractures. Impairment of knee joint stability as an indication for surgical treatment. J Bone Joint Surg Am. 1973;55(7): 1331-50.

15. Lansinger O, Bergman B, Körner L, Andersson GB. Tibial condylar fractures. A twenty-year follow-up. J Bone Joint Surg Am. 1986;68(1):13-9.

16. Jiang R, Luo CF, Wang MC, Yang TY, Zeng BF. A comparative study of Less Invasive Stabilization system (LISS) fixation and two-incision double plating for the treatment of bicondylar tibial plateau fractures. Knee. 2008;15(2):139-43.

17. Krupp RJ, Malkani AL, Roberts CS, Seligson D, Crawford CH 3rd, Smith L. Treatment of bicondylar tibia plateau fractures using locked plating versus external fixation. Orthopedics. 2009;32(8).

18. Bek D, Özdemir S, Tunay S, Kılıç E, Altınmakas M. Tibia plato kırıklarının artroskopi yardımlı perkütan fiksasyonu. Gülhane Tıp Dergisi. 2005;(47):190-4.

19. Rozbruch SR, Segal K, Ilizarov S, Fragomen AT, Ilizarov G. Does the Taylor Spatial Frame accurately correct tibial deformities? Clin Orthop Relat Res. 2010;468(5):1352-61.

20. Manner HM, Huebl M, Radler C, Ganger R, Petje G, Grill F. Accuracy of complex lower-limb deformity correction with external fixation: a comparison of the Taylor Spatial Frame with the Ilizarov ring fixator. J Child Orthop. 2007;1(1):55-61 